\title{
Comparison of children's food and beverage intakes with national recommendations in New York City child-care centres
}

\author{
L Beth Dixon ${ }^{1, *}$, Andrew Breck ${ }^{2,3}$ and Laura Kettel Khan ${ }^{4}$
}

${ }^{1}$ Department of Public Health, Food Studies and Nutrition, Syracuse University, 415 Sims Building, 26 Ostrom Avenue, Syracuse, NY 13078, USA: '2Department of Population Health, New York University School of Medicine, New York, NY, USA: ${ }^{3}$ Department of Public Administration, New York University Wagner School of Public Service, New York, NY, USA:

${ }^{4}$ Division of Nutrition, Physical Activity, and Obesity, Centers for Disease Control and Prevention, Atlanta, GA, USA

Submitted 3 August 2015: Final revision received 20 March 2016: Accepted 14 April 2016: First published online 10 June 2016

\begin{abstract}
Objective: The present study compared foods and beverages provided to and consumed by children at child-care centres in New York City (NYC) with national nutrition recommendations.

Design: The study used survey, observational and centre record data collected from child-care centres. Food and beverage intakes from two days of observation and amounts of energy and nutrients were estimated using the US National Cancer Institute's Automated Self-Administered $24 \mathrm{~h}$ Recall system.

Setting: Meal and snack time at 108 child-care centres in low-income communities in NYC.

Subjects: Children aged 3-4 years old in classrooms selected by the directors of the participating child-care centres.

Results: Foods and beverages provided to and consumed by children ( $n$ 630) met $>50 \%$ of the Dietary Reference Intake (DRI) for most nutrients. Intakes of fibre and vitamins D and $\mathrm{E}$ were $<30 \%$ of the DRI. Foods and beverages provided $>50 \%$ of the recommended average daily intake amounts for total grains, fruits and fruit juices, and dairy, but $<50 \%$ of the recommended amounts for whole grains, protein foods and vegetables. Intake of oils was below the allowance for energy levels, but foods and beverages with solid fats and added sugars exceeded the limits by $68 \%$.

Conclusions: Providing more whole grains, vegetables and low-fat dairy and fewer foods with solid fats and added sugars may improve children's diet quality when at child-care centres. Centre staff may need training, resources and strategies in order to meet the nutrition recommendations.
\end{abstract}

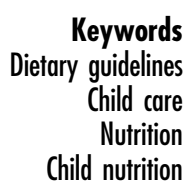

Nationally representative data from 2011-2012 show that $23 \%$ of children aged $2-5$ years were overweight or obese $^{(1)}$. Child-care centres have been identified as an important setting to improve nutrition practices and prevent childhood obesity ${ }^{(2)}$. According to the recent White House Task Force on Childhood Obesity Report to the President, a quality child-care setting is one that provides nutritious foods, opportunities for children to be physically active and limits screen time ${ }^{(3)}$. In response, Let's Move! Child Care was released in June 2011 with a five-item checklist including recommendations for healthful eating, physical activity and screen time to be implemented in child-care centres throughout the USA ${ }^{(4)}$.

Efforts to improve the nutrition and physical activity environment in child-care centres in New York City (NYC) began in 2005 when high levels of overweight children were identified in Head Start centres ${ }^{(5)}$. Erinosho et al. worked with colleagues at the NYC Department of Health and Mental Hygiene to evaluate the nutrition practices in forty child-care centres in underserved communities in $\mathrm{NYC}^{(6)}$. Results from this work contributed to the development of formal regulations for beverages, physical activity and screen time in licensed group child-care centres in NYC. These regulations were added to the NYC Health Code and went into effect on 1 January $2007^{(7)}$.

The Academy of Nutrition and Dietetics recommends that all foods and beverages provided to children in child-care programmes meet the Dietary Guidelines for Americans and that children in full-time programmes receive foods and beverages that meet $50-67 \%$ of their daily nutrient needs ${ }^{(8)}$. One approach for evaluating the quality of children's dietary intakes at full-time child-care programmes is to compare the nutrient contents and amounts of foods and beverages with national recommendations including the Dietary Reference 
Intakes (DRI) ${ }^{(9)}$ and the Dietary Guidelines for Americans $2010^{(10)}$. A few studies have assessed the quality of children's dietary intakes at centres in different regions of the country; however, many of these studies compared only nutrients or foods (not both) with national recommendations ${ }^{(6,11-16)}$. The purpose of the present study was to evaluate children's diet quality at full-time centres in low-income communities in NYC by comparing both nutrient contents and amounts of foods and beverages with national recommendations and the recommendations of the Academy of Nutrition and Dietetics.

\section{Methods}

\section{Study design and sample}

The NYC Child Care Evaluation was a multi-method, cross-sectional study conducted to determine compliance with current city health department regulations for beverages, physical activity and screen time at licensed group child-care centres in NYC. In Evaluation Component I (October 2009-January 2010), 176 licensed child-care centres were randomly sampled from low-income neighbourhoods where survey, observational and centre record data were collected. In Evaluation Component II (April-June 2010), 110 of the 176 centres agreed to collection of children's dietary intake data from two days of observation ${ }^{(17)}$. In this study, six different children at each centre were observed over the two-day collection period. The final sample size was 630 children because two centres out of the 110 centres did not provide food, five centres only had one site visit and three children had observations with incomplete data (i.e. \{3 children/ centre $\times[(110$ centres -2 centres $) \times 2$ site visits $]\}-$ [15 observations (due to 5 missing site visit days)](3 observations with incomplete data)).

\section{Dietary assessment}

In 2010, teams of two evaluation staff visited the 110 childcare centres on two consecutive days. In classrooms of children aged 3-4 years old selected by the centre director, one data collector recorded information about the quantity, content and preparation of all foods and beverages provided to children. When types of foods and beverages were unclear by direct observation (e.g. type of milk or juice), the data collector read labels on the food and beverage products and asked teachers and food-service staff for further information. The second data collector selected three children on each observation day and discreetly recorded all types and quantities of foods and beverages consumed. Direct observation by both data collectors was conducted from a distance. The children did not interact with the data collectors and were generally uninterested in their presence. Direct observation of children's food and beverage consumption has been shown to be a valid and reliable method in child-care settings. A single trained evaluator can observe the dietary intakes of up to three young children ${ }^{(18)}$. Prior to the site visits, the data collectors were trained in estimating portion sizes of foods and beverages.

\section{Data analysis}

All information about the foods and beverages provided to and consumed by the children was entered into the US National Cancer Institute's Automated Self-Administered 24-h Recall (ASA24) system $^{(19)}$. The ASA24 is linked to the Food and Nutrient Database for Dietary Studies version $4.1^{(20)}$ and the MyPyramid Equivalents Database version $2^{(21)}$ from the US Department of Agriculture (USDA) and was used to generate estimates for energy, nutrients and amounts of food groups. Microsoft ${ }^{\circledR}$ Excel 2007 (v12.0) was used to average the nutrition values for all foods and beverages provided to and consumed by the observed children during the two site visit days.

Energy and nutrient intakes averaged from the two site visit days were compared with the DRI for 1-3-year-old children $(1200 \mathrm{kcal}(5021 \mathrm{~kJ}))$ and 4-8-year-old children $(1400 \mathrm{kcal}(5858 \mathrm{~kJ}))^{(9)}$. Mean amounts of food groups and subgroups were compared with the recommended daily amounts for two energy levels of USDA Food Patterns in the Dietary Guidelines for Americans 2010 ${ }^{(10)}$. Two sets of DRI recommendations and two energy levels of USDA Food Patterns were selected because they are appropriate for boys and girls aged 3-4 years old who are moderately active.

The Academy of Nutrition and Dietetics recommends that children in full-time programmes receive foods and beverages that meet at least $50-67 \%$ of their daily nutrient needs ${ }^{(8)}$. Therefore, $50-67 \%$ of the DRI and the 1200 and $1400 \mathrm{kcal}$ (5021 and $5858 \mathrm{~kJ}$ ) energy level plans from the Dietary Guidelines for Americans 2010 were used to evaluate the nutritional quality of the foods and beverages provided to and consumed by the observed children.

\section{Results}

Table 1 shows mean energy and nutrient intakes from foods and beverages provided to and consumed by children at full-time child-care centres during two days of data collection and the respective DRI for children aged 1-3 years and 4-8 years ${ }^{(9)}$.

Foods and beverages provided an average of $66 \%$ of the DRI for energy for 1-3-year-olds and $57 \%$ of the DRI for energy for 4-8-year-olds, and more than two-thirds of the DRI for macronutrients, minerals and most vitamins for both age groups. However, foods and beverages provided $<40 \%$ for fibre, $<36 \%$ for vitamin D and $<46 \%$ of the DRI for vitamin $\mathrm{E}$ for both age groups of children.

During the two days of observation, foods and beverages consumed by the children met $>50 \%$ of the DRI for most nutrients. However, children consumed between 40 and $47 \%$ of the DRI for energy, $20-27 \%$ of the DRI for 
Table 1 Mean energy and nutrient intakes from foods and beverages provided to and consumed by 3-4-year-old children during two days of observation at child-care centres in New York City, April-June 2010

\begin{tabular}{|c|c|c|c|c|c|c|c|c|}
\hline & \multirow{2}{*}{\multicolumn{2}{|c|}{ DRIt }} & \multicolumn{3}{|c|}{ From foods and beverages provided $(n 211)^{\star}$} & \multicolumn{3}{|c|}{ From foods and beverages consumed $(n 630)^{\star}$} \\
\hline & & & \multirow{2}{*}{$\begin{array}{l}\text { Mean } \\
\text { amount }\end{array}$} & \multicolumn{2}{|c|}{$\%$ of DRI } & \multirow{2}{*}{$\begin{array}{l}\text { Mean } \\
\text { amount }\end{array}$} & \multicolumn{2}{|c|}{$\%$ of DRI } \\
\hline & $1-3$ yearsł & 4-8 years $\ddagger$ & & $1-3$ years & $4-8$ years & & $1-3$ years & $4-8$ years \\
\hline \multicolumn{9}{|c|}{ Energy and macronutrients } \\
\hline Energy (kcal) & 1200 & 1400 & 791.8 & $66 \cdot 0$ & $56 \cdot 6$ & $564 \cdot 3$ & $47 \cdot 0$ & $40 \cdot 3$ \\
\hline Energy (kJ) & 5021 & 5858 & 3313 & $66 \cdot 0$ & $56 \cdot 6$ & 2361 & $47 \cdot 0$ & $40 \cdot 3$ \\
\hline Carbohydrate (g) & 130 & 130 & $110 \cdot 5$ & $85 \cdot 0$ & $85 \cdot 0$ & 78.5 & $60 \cdot 4$ & $60 \cdot 4$ \\
\hline Fibre $(\mathrm{g})$ & 19 & 25 & $7 \cdot 6$ & $40 \cdot 0$ & $30 \cdot 4$ & $5 \cdot 2$ & $27 \cdot 4$ & $20 \cdot 8$ \\
\hline Fat $(\mathrm{g})$ & $30-45$ & $25-35$ & $25 \cdot 4$ & 67.8 & 84.8 & $18 \cdot 3$ & $48 \cdot 8$ & $61 \cdot 0$ \\
\hline Protein $(g)$ & 13 & 19 & 33.6 & $258 \cdot 6$ & $176 \cdot 9$ & $23 \cdot 7$ & $182 \cdot 6$ & $125 \cdot 0$ \\
\hline \multicolumn{9}{|l|}{ Vitamins } \\
\hline Thiamin (mg) & 0.5 & 0.6 & 0.7 & $140 \cdot 0$ & $116 \cdot 6$ & 0.5 & $96 \cdot 4$ & $80 \cdot 3$ \\
\hline Riboflavin (mg) & 0.5 & 0.6 & $1 \cdot 3$ & $262 \cdot 4$ & $218 \cdot 7$ & 0.9 & 173.9 & $145 \cdot 0$ \\
\hline Niacin $(\mathrm{mg})$ & 6 & 8 & $8 \cdot 7$ & $145 \cdot 1$ & $108 \cdot 8$ & $6 \cdot 1$ & $102 \cdot 1$ & $76 \cdot 7$ \\
\hline Pyridoxine (mg) & 0.5 & 0.6 & 0.9 & 178.6 & 148.9 & 0.6 & $118 \cdot 1$ & 98.8 \\
\hline Folate $(\mu \mathrm{g})$ & 150 & 200 & 194.1 & $129 \cdot 4$ & $97 \cdot 0$ & $131 \cdot 2$ & $87 \cdot 4$ & $65 \cdot 6$ \\
\hline Vitamin $B_{12}(\mu \mathrm{g})$ & 0.9 & $1 \cdot 2$ & 3.2 & $359 \cdot 9$ & $269 \cdot 9$ & $2 \cdot 1$ & 233.5 & $175 \cdot 1$ \\
\hline Vitamin A (RE) & 300 & 400 & $478 \cdot 7$ & $159 \cdot 6$ & $119 \cdot 7$ & $305 \cdot 6$ & 101.9 & 76.4 \\
\hline Vitamin C (mg) & 15 & 25 & $49 \cdot 9$ & 332.5 & 199.5 & $35 \cdot 8$ & 238.3 & $143 \cdot 0$ \\
\hline Vitamin E (mg a) & 6 & 7 & $2 \cdot 8$ & $45 \cdot 8$ & 39.2 & $1 \cdot 8$ & $29 \cdot 6$ & $25 \cdot 4$ \\
\hline Vitamin $D(\mu \mathrm{g})$ & 15 & 15 & $5 \cdot 3$ & $35 \cdot 6$ & $35 \cdot 6$ & 3.5 & $23 \cdot 3$ & $23 \cdot 3$ \\
\hline Vitamin K ( $\mu \mathrm{g})$ & 30 & 55 & $54 \cdot 6$ & 181.9 & $99 \cdot 2$ & 31.9 & $106 \cdot 6$ & $58 \cdot 1$ \\
\hline \multicolumn{9}{|l|}{ Minerals } \\
\hline $\mathrm{Ca}(\mathrm{mg})$ & 700 & 1000 & 691.72 & $98 \cdot 8$ & $69 \cdot 2$ & $456 \cdot 0$ & $65 \cdot 2$ & $45 \cdot 6$ \\
\hline $\mathrm{Fe}(\mathrm{mg})$ & 7 & 10 & $6 \cdot 70$ & $95 \cdot 7$ & 67.0 & 4.5 & 64.9 & $45 \cdot 4$ \\
\hline $\mathrm{Mg}(\mathrm{mg})$ & 80 & 130 & $125 \cdot 51$ & $156 \cdot 9$ & $96 \cdot 5$ & $86 \cdot 0$ & $107 \cdot 04$ & $66 \cdot 2$ \\
\hline $\mathrm{Zn}(\mathrm{mg})$ & 3 & 5 & 5.06 & 168.5 & $101 \cdot 1$ & 3.4 & $113 \cdot 3$ & 68.0 \\
\hline
\end{tabular}

DRI, Dietary Reference Intake; RE, retinol equivalents.

*Mean amounts of energy and nutrients from foods and beverages provided to children were estimated from 211 centre visits; mean amounts of energy and nutrients from foods and beverages consumed by children were estimated from 630 observed children.

†Recommendations for individuals of the US Department of Agriculture, Food and Nutrition Service ${ }^{(9)}$.

$\ddagger$ Two age categories for DRI were selected for comparison because the observed children were 3 and 4 years old.

fibre, $23 \%$ of the DRI for vitamin D and $25-30 \%$ of the DRI for vitamin E. Children consumed $65 \%$ of the DRI for Ca and Fe for 1-3-year-old children but only $45 \%$ of the DRI for $\mathrm{Ca}$ and $\mathrm{Fe}$ for 4-8-year-old children.

Table 2 shows mean amounts of food groups and subgroups, oils, and solid fats and added sugars (SoFAS) in comparison with the recommended daily intake amounts for two USDA Food Patterns in the Dietary Guidelines for Americans 2010 ${ }^{(10)}$. Fruits and fruit juices and dairy provided to the children were $>50 \%$ of the recommended amounts for both age groups. Total grains were 52-66\% of the recommendations but whole grains were $<25 \%$ of the recommendations. Total and all subtypes of vegetables were $32-46 \%$ of the recommendations. Oils from foods were only $26 \%$ of the allowance for intake, but SoFAS were $>68 \%$ of the maximum recommendation for both energy level food patterns.

Children's intakes of almost all food groups and subgroups were $<50 \%$ of the recommended average daily amounts and were especially low for whole grains and most subgroups of vegetables for both energy level food patterns. Children's intake of fruits and fruit juices was $>50 \%$ compared with the recommended amount for the $1200 \mathrm{kcal}$ ( $5021 \mathrm{~kJ}$ ) level but $<50 \%$ compared with the recommended amount for the $1400 \mathrm{kcal}(5858 \mathrm{~kJ})$ level. For both energy level food patterns, children's intake of oils was $<15 \%$ of the allowance for intake, but children's intake of SoFAS was $>23 \%$ of the maximum recommendation.

\section{Discussion}

Results from the present study suggest potential ways to improve the quality of children's dietary intakes at child-care centres. These suggestions include maintaining the amounts of total grains, fruits and fruit juices, protein foods and dairy; increasing the amounts of whole grains, vegetables, and dietary sources of fibre, vitamins D and E; and offering fewer foods and beverages with SoFAS.

Nutrition surveillance data show that many young children in the USA have low intakes of these foods and nutrients and high intake of SoFAS ${ }^{(22)}$. Other studies have assessed dietary intakes of children at child-care centres in other regions of the country. Although the dietary recommendations (e.g. RDA $v$. DRI, original Food Guide Pyramid $v$. MyPyramid Equivalent Food Groups) differed between studies, results from these studies are similar to national surveillance data and to our results in NYC child-care centres. For example, in nine Head Start centres in New York State, Bollella et al. ${ }^{(12)}$ observed 358 children 
Table 2 Mean amounts of MyPyramid Equivalent Food Groups from foods and beverages provided to and consumed by 3-4-year-old children during two days of observation at child-care centres in New York City, April-June 2010

\begin{tabular}{|c|c|c|c|c|c|c|c|c|}
\hline \multirow[b]{2}{*}{$\begin{array}{l}\text { MyPyramid Equivalent } \\
\text { Food Groups* }\end{array}$} & \multicolumn{2}{|c|}{$\begin{array}{l}\text { Recommended daily } \\
\text { amounts of food } \\
\text { groups in two USDA } \\
\text { Food Patterns } †\end{array}$} & \multicolumn{3}{|c|}{$\begin{array}{l}\text { From foods and beverages } \\
\text { provided }(n 211) \ddagger\end{array}$} & \multicolumn{3}{|c|}{$\begin{array}{l}\text { From foods and beverages } \\
\text { consumed }(n 630) \ddagger\end{array}$} \\
\hline & $1200 \mathrm{kcal} \S$ & $1400 \mathrm{kcal} \S$ & $\begin{array}{l}\text { Mean } \\
\text { amount }\end{array}$ & $\begin{array}{l}\% \text { of } 1200 \mathrm{kcal} \\
\text { Food Pattern§ }\end{array}$ & $\begin{array}{l}\% \text { of } 1400 \mathrm{kcal} \\
\text { Food Pattern§ }\end{array}$ & $\begin{array}{l}\text { Mean } \\
\text { amount }\end{array}$ & $\begin{array}{l}\% \text { of } 1200 \mathrm{kcal} \\
\text { Food Pattern§ }\end{array}$ & $\begin{array}{l}\% \text { of } 1400 \mathrm{kcal} \\
\text { Food Pattern§ }\end{array}$ \\
\hline Grains (oz) & 4.00 & $5 \cdot 00$ & $2 \cdot 62$ & $65 \cdot 5$ & $52 \cdot 4$ & 1.94 & $48 \cdot 5$ & 38.8 \\
\hline Whole grains\|l & $2 \cdot 00$ & 2.50 & 0.49 & 24.6 & $19 \cdot 6$ & 0.37 & $18 \cdot 6$ & 14.9 \\
\hline Vegetables $(\mathrm{c})$ & 1.50 & 1.50 & 0.53 & $35 \cdot 4$ & $35 \cdot 4$ & 0.31 & 20.9 & 20.9 \\
\hline Dark green & 0.14 & 0.14 & 0.06 & 39.7 & 39.7 & 0.03 & $22 \cdot 4$ & $22 \cdot 4$ \\
\hline Red and orange & 0.43 & 0.43 & 0.16 & $36 \cdot 4$ & $36 \cdot 4$ & 0.11 & 24.7 & 24.7 \\
\hline Beans and peas (legumes) & 0.07 & 0.07 & 0.03 & $42 \cdot 4$ & $42 \cdot 4$ & 0.02 & $26 \cdot 1$ & $26 \cdot 1$ \\
\hline Starchy & 0.50 & 0.50 & 0.16 & $32 \cdot 0$ & $32 \cdot 0$ & 0.09 & $18 \cdot 1$ & $18 \cdot 1$ \\
\hline Other & 0.37 & 0.37 & 0.17 & $45 \cdot 8$ & $45 \cdot 8$ & 0.09 & 23.2 & $23 \cdot 2$ \\
\hline Fruits and Fruit Juices (c) & 1.00 & 1.50 & 0.94 & 94.0 & $62 \cdot 7$ & 0.71 & 71.2 & $47 . \overline{5}$ \\
\hline 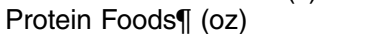 & 3.00 & 4.00 & 1.27 & $42 \cdot 2$ & 31.6 & 1.00 & 33.2 & 24.9 \\
\hline Dairy $^{\star *}(\mathrm{c})$ & 2.50 & 2.50 & 1.76 & $70 \cdot 5$ & $70 \cdot 5$ & $1 \cdot 16$ & $35 \cdot 1$ & $35 \cdot 1$ \\
\hline Oilst† (kcal) & 153 & 153 & 39.05 & 25.5 & $25 \cdot 5$ & $22 \cdot 83$ & 14.9 & 14.9 \\
\hline SoFAS㧊 (kcal) & 121 & 121 & 203.43 & $168 \cdot 1$ & $168 \cdot 1$ & 149.04 & $123 \cdot 2$ & $123 \cdot 2$ \\
\hline
\end{tabular}

USDA, US Department of Agriculture.

$1 \mathrm{kcal}=4.184 \mathrm{~kJ}$. 1 cup (c) is equivalent to 0.2366 litres; 1 ounce (oz) is equivalent to $29.5735 \mathrm{ml}$.

*Food Groups from the MyPyramid Equivalents Database version $2^{(20)}$

†Food Patterns from the Dietary Guidelines for Americans $2010^{(10)}$

¥Mean amounts of energy and nutrients from foods and beverages provided to children were estimated from 211 centre visits; mean amounts of energy and nutrients from foods and beverages consumed by children were estimated from 630 observed children.

§Two USDA Food Patterns (1200 and $1400 \mathrm{kcal}(5021$ and $5858 \mathrm{~kJ})$ ) were selected for comparison because they are appropriate for 3- and 4-year-old children who are active for at least 30-60 min daily ${ }^{(10)}$.

IWhole grains includes all whole grain products that are both $100 \%$ and $<100 \%$ whole grain and whole grains that are used as ingredients.

IIn the Dietary Guidelines for Americans $2010^{(10)}$, the recommended amounts for vegetables and protein foods subgroups are given as weekly amounts; the recommended amounts are converted to daily amounts in the current table. Protein foods include lean meat from beef, pork, veal, lamb, game, organ meats, frankfurters, sausages and luncheon meat; poultry; and fish and shellfish, soya, nuts and eggs.

**Dairy foods include milk, yoghurt, frozen yoghurt, dairy desserts and cheeses.

††Oils include vegetable, nut and fish oils and soft vegetable oil table spreads.

$\ddagger \mp$ SoFAS are calories from solid fats and added sugars. According to the Dietary Guidelines for Americans $2010^{(10)}$, the limit for SoFAS is the remaining amount of calories in each food pattern after selecting the specified amounts in each food group in nutrient-dense forms (forms that are fat-free or low-fat and with no added sugars).

aged 4-6 years and found that intakes of energy, Ca and Fe were $<50 \%$ of the RDA. In twelve child-care centres in central Texas, Briley et al. ${ }^{(13)}$ observed fifty-one children and found that less than half of the children consumed at least $50 \%$ of the RDA for energy and Fe. In two centres in New Jersey, Bruening et al. ${ }^{(14)}$ collected $14 \mathrm{~d}$ of diet records from forty children and found their mean intakes of vitamin $\mathrm{E}$, folate, $\mathrm{Ca}, \mathrm{Fe}$ and $\mathrm{Zn}$ to be $<67 \%$ of the RDA. In four child-care centres in Missouri, Drake ${ }^{(15)}$ observed that energy and Fe intakes were $<50 \%$ of the RDA for 4-6-year-old children.

With regard to food group intakes, in twenty centres in North Carolina, Ball et al. ${ }^{(11)}$ observed 117 children and estimated that they consumed $<50 \%$ of recommended servings for grains, vegetables, fruits and meats. Intakes of whole grains and dark green and orange vegetables were especially low ( $13 \%$ and $7 \%$ of the recommendations, respectively). In forty child-care centres in NYC, Erinosho et $a l^{(6)}$ observed 240 children and found that only $17 \%$ of children had vegetable intakes $>50 \%$ of the respective daily recommendations. In nine centres in central Texas, Padget and Briley ${ }^{(16)}$ collected $3 \mathrm{~d}$ of food records from fifty children and showed that 3 -year-old children consumed $<67 \%$ of the recommended number of servings for grains, vegetables and dairy, and 4 - and 5-year-old children consumed $<67 \%$ of the recommended number of servings for meats, grains, vegetables and dairy. In that study, amounts of fats, oils and sugars were not assessed because intakes were compared with the Food Guide Pyramid for Young Children and optimal intakes of those dietary components were not specified.

The mean amounts of protein determined from foods and beverages provided to and consumed by the children in the present study were greater than both sets of DRI recommendations. In contrast, the mean intake of the protein food group that includes meat, poultry, seafood, eggs, nuts, seeds and processed soya products was less than half that recommended by the USDA Food Plans for energy level of 1200 or $1400 \mathrm{kcal}(5021$ or $5858 \mathrm{~kJ}$ ). This discrepancy can be explained by the fact that sources of protein also include dairy foods, grains and some vegetable food groups (i.e. beans and peas). Also, even though the estimate for mean daily protein intake was higher than the DRI for what was provided (i.e. $34 \mathrm{~g}$ ) and what was consumed (i.e. $24 \mathrm{~g}$ ), these values are about half of the amounts determined from $24 \mathrm{~h}$ dietary recalls from caregivers of 2-5-year-old children in the What We Eat In 
America component of the National Health and Nutrition Examination Survey 2011-2012 ${ }^{(22)}$.

\section{Implications for dietary guidance}

In the last decade, there have been efforts at the local, state and federal levels to improve the nutrition practices in early child-care settings. In NYC, the nutrition policies for child-care centres as issued in Article 47 of the NYC Health Code focus on beverages, specifically to encourage consumption of low-fat (skimmed or $1 \%$ ) milk and water and a maximum intake of no more than 6 ounces $(177 \mathrm{ml})$ of $100 \%$ fruit juice ${ }^{(7)}$. The policies also state that 'Food supplied to children shall be wholesome, of good quality, properly prepared in accordance with nutritional guidelines provided or approved by the Department, and age-appropriate in portion size and variety'. Another source of guidance for child-care centres that serve lowincome families is the Child and Adult Care Food Program (CACFP $)^{(23)}$. To qualify for reimbursement, the centres have to serve meals and snacks that meet the CACFP nutrition requirements in terms of amounts and types of foods and beverages for each meal or snack. In 2009, the New York State CACFP modified its Child Meal Patterns to be in accordance with the Dietary Guidelines for Americans to reduce risk of overweight, obesity and chronic disease ${ }^{(24)}$. In 2010, the Institute of Medicine convened a panel of experts to revise the CACFP nutrition requirements to align with the Dietary Guidelines for Americans and the DRI ${ }^{(25)}$. The Institute of Medicine committee recommended changes to meal patterns for breakfast, lunch, supper and snacks to 'increase the variety of fruits and vegetables, increase the proportion of whole grains, and decrease the content of solid fats, added sugars, trans fats, and sodium.'

Providing recommendations and policies is not sufficient, however, without training and technical assistance. Results from Evaluation Component I of the NYC Child Care Evaluation in 176 centres showed that prior training and technical assistance was associated with compliance with the physical activity regulations but not with the beverage regulations ${ }^{(26)}$. Likewise, a survey of 118 child-care providers in 2011 and 2012 by the Academy of Nutrition and Dietetics showed that training of child-care providers was needed to teach positive eating behaviours and self-regulation to prevent childhood obesity $^{(27)}$. In the study by Erinosho et al., teachers and staff requested training and resources specifically about how to encourage children to eat more vegetables and whole grains, and to try foods and beverages that may not be familiar to them ${ }^{(6)}$.

Some studies have been successful at improving children's dietary intake in child-care settings. Sigman-Grant et al. showed that training providers to role model and adopt appropriate feeding strategies that support healthy weight in young children created a supportive mealtime environment for obesity prevention ${ }^{(28)}$. In a study by
Benjamin et al., parents recommended that meals and snacks be improved by adding fruits and vegetables ${ }^{(29)}$. Roe et al. showed that serving a variety of vegetables and fruits in the afternoon snack did increase intake of these foods ${ }^{(30)}$. Reicks et al. showed that adding photographs of vegetables to meal trays in cafeterias at elementary schools increased children's consumption of those foods ${ }^{(31)}$. Kharofa et al. found that staff behaviour at mealtime, including sitting with the children during mealtime and eating some of the same foods, increased vegetable intake ${ }^{(32)}$.

It is also important to provide nutrition education to parents and primary caregivers of young children, especially because types of foods and beverages offered to children at home may be less healthful than those offered at child-care centres. For example, Erinosho et $a l .{ }^{(33)}$ showed that children were more likely to consume high-fat milk (e.g. whole or $2 \%$ milk), soft drinks and French fries at home than when at child care. These unhealthy eating behaviours were associated with eating meals at fast-food or other restaurants more than once weekly and whether the child ate food while watching television. Other studies of similarly aged children have shown that food choices improved at home and saturated fat intake was lowered when children received nutrition education in child-care settings ${ }^{(34,35)}$.

\section{Strengths and limitations}

The present study has several strengths, most notably the careful collection of dietary intake data by direct observation of young children in classrooms at the centres. Although not perfect, direct observation by trained data collectors is considered to be the best method to assess foods and beverages consumed by young children ${ }^{(18)}$. Also, to improve accuracy, foods and beverages that were not readily identifiable (e.g. type of milk) were clarified with teachers and food-service staff. Another strength was the analysis of nutrient content of the foods and beverages provided and consumed. Use of the National Cancer Institute's ASA24 system $^{(19)}$ allows estimation of energy and nutrient intakes and servings of foods from food groups and sub-food groups included in the MyPyramid Equivalents Database that align with the food groups included in the USDA Food Patterns in the Dietary Guidelines for Americans $2010^{(10)}$. Although other studies have compared children's food intakes with serving recommendations for food groups, the present study allowed for estimation of SoFAS which is a new feature of the National Cancer Institute's ASA24 system compared with other dietary analysis software systems. It is, however, important to recognize that assessment of dietary intakes of small children is still a difficult task due to possible errors throughout the process of observation and recording. Also, although two days of observations were conducted at the centres, different children were observed 
for each day so the dietary data do not reflect usual intake of an individual child.

\section{Conclusions}

Results from the present study describe nutrition practices in a sample of licensed group child-care centres located mostly in low-income neighbourhoods in NYC. Serving more whole grains, vegetables and low-fat dairy and fewer foods with SoFAS may improve the overall dietary quality of young children in these child-care settings. Centre staff may need training, resources and strategies to encourage children to eat healthful foods that meet national nutrition recommendations and the recommendations by the Academy of Nutrition and Dietetics.

\section{Acknowledgements}

Acknowledgments: Technical assistance was provided by the National Center for Chronic Disease Prevention and Health Promotion, Division of Nutrition, Physical Activity and Obesity of the Centers for Disease Control and Prevention (CDC). ICF International served as the lead contractor for the study in conjunction with the NYC Department of Health and Mental Hygiene. The authors thank the centre directors, teachers and staff for their help with data collection. They also thank two students (Minh Tieu, Simone Walters) who helped enter dietary data into the ASA24 system. The findings and conclusions in this report are those of the authors do not necessarily represent the official position of the CDC or any of the other project agencies. Financial support: This project was funded by a grant from the Robert Wood Johnson Foundation (number 65425) to the National Foundation for the CDC. Conflict of interest: None. Authorship: L.B.D. assisted in designing the study, provided guidance on the analysis, and took primary responsibility for drafting this manuscript. A.B. contributed to data collection, conducted the analysis, and provided substantial contributions to the substance and editing of the paper. L.K.K. conceptualized and oversaw this study, provided guidance on the analysis, and provided substantial contributions to the substance and editing of the paper. Ethics of buman subject participation: This study was conducted according to the guidelines laid down in the Declaration of Helsinki and all procedures involving human subjects/patients were approved by the institutional review boards of the New York City Department of Health and Mental Hygiene and ICF International.

\section{References}

1. Ogden CL, Carroll MD, Kit BK et al. (2014) Prevalence of childhood and adult obesity in the United States, 2011-2012. JAMA 311, 806-814.

2. Larson N, Ward DS, Neelon SB et al. (2011) What role can child-care settings play in obesity prevention? A review of the evidence and call for research efforts. J Am Diet Assoc 111, 1343-1362.

3. White House Task Force on Childhood Obesity (2010) Report to the President: Solving the problem of childhood obesity within a generation. http://www.letsmove.gov/ sites/letsmove.gov/files/TaskForce_on_Childhood_Obesity_ May2010_FullReport.pdf (accessed May 2014).

4. The Nemours Foundation (2011) Let's Move! Child Care. http://healthykidshealthyfuture.org/welcome.html (accessed May 2015).

5. Young CR, Peretz P, Jaslow R et al. (2006) Obesity in early childhood: more than $40 \%$ of Head Start children in NYC are overweight or obese. NYC Vital Signs 5, 1-2.

6. Erinosho T, Dixon LB, Young C et al. (2011) Nutrition practices and children's dietary intakes at 40 child-care centers in New York City. J Am Diet Assoc 111, 1391-1397.

7. New York City Department of Health and Mental Hygiene Board of Health (2008) Notice of adoption amendments to Article 47 of the New York City Health Code. http://www. nyc.gov/html/doh/downloads/pdf/public/notice-adoptionhc-art47-0308.pdf (accessed May 2015).

8. Benjamin Neelon SE \& Briley ME (2011) Position of the American Dietetic Association: Benchmarks for nutrition programs in child care settings. J Am Diet Assoc 111, 607-615.

9. US Department of Agriculture, Food and Nutrition Service (2006) Dietary Reference Intakes: the Essential Guide to Dietary Nutrients. http://fnic.nal.usda.gov/dietary-guidance/ dietary-reference-intakes (accessed May 2015).

10. US Department of Agriculture \& US Department of Health and Human Services (2010) Dietary Guidelines for Americans 2010. http://health.gov/dietaryguidelines/dga2010/ DietaryGuidelines2010.pdf (accessed May 2015).

11. Ball SC, Benjamin SE \& Ward DS (2008) Dietary intakes in North Carolina child-care centers: are children meeting current recommendations? J Am Diet Assoc 108, 718-721.

12. Bollella MC, Spark A, Boccia LA et al. (1999) Nutrient intake of Head Start children: home vs. school. J Am Coll Nutr 18, 108-114.

13. Briley ME, Jastrow S, Vickers J et al. (1999) Dietary intake at child-care centers and away: are parents and care providers working as partners or at cross-purposes? J Am Diet Assoc 99, 950-954.

14. Bruening KS, Gilbride JA, Passannante MR et al. (1999) Dietary intake and health outcomes among young children attending 2 urban day-care centers. J Am Diet Assoc 99, 1529-1535.

15. Drake MA (1992) Menu evaluation, nutrient intake of young children, and nutrition knowledge of menu planners in child care centers in Missouri. J Nutr Educ 24, 145-148.

16. Padget A \& Briley ME (2005) Dietary intakes at child-care centers in Central Texas fail to meet Food Guide Pyramid recommendations. J Am Diet Assoc 105, 790-793.

17. Breck A, Goodman K, Dunn L et al. (2014) Evaluation design of New York City's regulations on nutrition, physical activity, and screen time in early child care centers. Prev Chronic Dis 11, 130431.

18. Ball SC, Benjamin SE \& Ward DS (2007) Development and reliability of an observation method to assess food intake of young children in child care. J Am Diet Assoc 107, 656-661.

19. National Institutes of Health (2009) Automated SelfAdministered 24-Hour Recall (ASA24), Beta version 2009. Bethesda, MD: National Cancer Institute.

20. US Department of Agriculture, Agricultural Research Service (2014) USDA Food and Nutrient Database for Dietary Studies 2011-2012. Food Surveys Research Group Home Page. http:// www.ars.usda.gov/ba/bhnrc/fsrg (accessed May 2015).

21. Bowman SA, Friday JE \& Moshfegh A (2008) MyPyramid Equivalents Database, 2.0 for USDA Survey Foods, 2003-2004. Beltsville, MD: Food Surveys Research Group, Beltsville Human Nutrition Research Center, Agricultural Research Service, 
US Department of Agriculture; available at http://www.ars.usda. gov/ba/bhnrc/fsrg

22. US Department of Agriculture, Agricultural Research Service (2014) Nutrient Intakes from Food and Beverages: Mean Amounts Consumed per Individual, by Gender and Age, What We Eat in America, NHANES 2011-2012. https:// www.ars.usda.gov/SP2UserFiles/Place/80400530/pdf/1112/ Table_1_NIN_GEN_11.pdf (accessed April 2016).

23. US Department of Agriculture (2010) Child and Adult Care Food Program. http://www.fns.usda.gov/cacfp/child-andadult-care-food-program (accessed May 2015).

24. New York State Department of Health (2009) Policy Memo 132C. http://www.health.ny.gov/prevention/nutrition/ cacfp/policymemo/no132c.htm (accessed May 2015).

25. Institute of Medicine (2011) Child and Adult Care Food Program: Aligning Dietary Guidance for All. Washington, DC: The National Academics Press.

26. Kakietek J, Dunn L, O'Dell SA et al. (2014) Training and technical assistance for compliance with beverage and physical activity components of New York City's regulations for early child care centers. Prev Chronic Dis 11, E177.

27. Dev DA \& McBride BA (2013) Academy of Nutrition and Dietetics Benchmarks for nutrition in child care 2011: are child-care providers across contexts meeting recommendations? J Acad Nutr Diet 113, 1346-1353.

28. Sigman-Grant M, Christiansen E, Fernandez G et al. (2011) Child care provider training and a supportive feeding environment in child care settings in 4 states, 2003. Prev Chronic Dis $\mathbf{8}$, A113.

29. Benjamin SE, Haines J, Ball SC et al. (2008) Improving nutrition and physical activity in child care: what parents recommend. J Am Diet Assoc 108, 1907-1911.

30. Roe LS, Meengs JS, Birch LL et al. (2013) Serving a variety of vegetables and fruit as a snack increased intake in preschool children. Am J Clin Nutr 98, 693-699.

31. Reicks M, Redden JP, Mann T et al. (2012) Photographs in lunch tray compartments and vegetable consumption among children in elementary school cafeterias. JAMA 307, 784-785.

32. Kharofa RY, Kalkwarf HJ, Khoury JC et al. (2016) Are mealtime best practice guidelines for child care centers associated with energy, vegetable, and fruit intake? Child Obes 12, 52-58.

33. Erinosho T, Dixon LB, Young C et al. (2013) Caregiver food behaviors are associated with dietary intakes of children outside of the childcare setting. Public Health Nutr 16, $1263-1272$.

34. Cason KL (2001) Evaluation of a preschool nutrition education program based on the theory of multiple intelligences. J Nutr Educ 33, 161-164.

35. Fitzgibbon ML, Stolley MR, Schiffer L et al. (2005) Two-year follow-up results for Hip-Hop to Health Jr.: a randomized controlled trial for overweight prevention in preschool minority children. J Pediatr 146, 618-625. 